\title{
Space Experiences of Women with Visual Impairment in Domestic Architecture
}

\author{
Indrati Prastiti, Arina Hayati, and Murni Rachmawati \\ Department of Architecture, Institut Teknologi Sepuluh Nopember, Surabaya \\ e-mail: arina_h@arch.its.ac.id
}

\begin{abstract}
Domestic space is where basic human needs are accommodated and understood to the function and its inhabitants. The basic understanding of using domestic space is human activities as a system of activity and areas as a system of settings. However, visual representation techniques in architecture have led to the discriminatory practices towards visually impaired who have limitations on the sense of sight as a primary tool in spatial perception. Thus, studies are necessary to explore the use of domestic space by visually impaired. This paper aims to study the experience of people with visually impaired doing their activities and using a domestic architecture based on the cognition and percetption of their senses. This phenomenological research is studied at the natural setting of domestic housing from the perspective of women with visual impairment who live in Surabaya. The participants are chosen who have actively and independently carried their daily activities in domestic space. The results of this study show women with visual impairment have a specific system of activities and system of settings related to how the senses affect the spatial behavior of visually impaired in accommodating their activities. By doing so, they are able to compromise and create a friendly and accessible domestic environment.
\end{abstract}

Keywords-Domestic Space, The Use of Space, System of Activity, Blind Women, Housing.

\section{INTRODUCTION}

A DVANCES in visual representation techniques in architecture have led to the dominance of visual experience compared to other sensory in experiencing space (Basyazici, 2013). Visually impaired, who are limited in visual experience, are more active in using non-visual senses as a central role in the formulation of spatial experience. Those senses include auditory (hearing), olfactory (smelling), and haptic (touching) (Basyazici, 2013). This has led to discriminatory practices in the needs of housing for disabilities (Hemingway, 2011). Disability in the environment is often identified as a minority group that is ignored in the design process of the environment, which is often designed for non-disabled (Imrie, 1998). The problem faced by disabilities not only comes from the level of accessibility (physical environment) but also related to how disabilities motivate themselves in a social environment.

Space created is a reflection of the activity setting where space is located, which is based on the knowledge and needs of occupants (Hidayatun, 2008). Domestic spaces are formed from functions that accommodate basic activities in inhabiting, such as sleeping, cooking, eating, and other household activities. Space then develops according to the needs of the occupants to create a dynamic relationship with the occupants (Oswald, 1987). The basic elements to understand the use of space, according to Amos Rapoport
(1998), are human activities as a system of activity and core areas as a system of settings. The system of setting is a general boundary consisting of several settings or locations, and the connecting network between locations has a certain home range radius that can be classified into daily, weekly, and monthly home ranges. Thus, when looking at the use of domestic space, it is necessary to look at the home range of activity settings, namely in space, dwelling, and neighborhood as access to or from dwelling (source).

When studying space experience, the use of space that related to the system of activity and setting of where the occupants lived, as well as the meaning constructed, can seen in Figure 1. Activity as a form of behavior that is shown to affect and affected by the physical arrangement (setting) of the space. Rapoport (1990) said that settings are created to support desired behavior. Those make architecture encloses behavior tightly, as well as activities, tend to shape architecture. So that by identifying the system of activities that occur in space will also identify the system of settings related to the elements in space. The experience of visually impaired in the domestic life can be understood by exploring the process of interaction between their activities and the domestic environment that takes place, whether a house accommodates the needs of visually impaired or not, as well as their strategies in making a home and its meaning. Therefore, Sixsmith (1986) implies that is important to examine the experience of daily life, in order to understand the complexity of domestic activities in the house.

Research related to the use and meaning of domestic space of visually impaired has been carried out by Basyazici (2013) and Branham and Kane (2015). Basyazici (2013) conducted a study on how non-visual sensory play a central role in the formulation of spatial experience for visually impaired. Branham and Kane (2015) conducted a study related to the relationship or collaboration between visually impaired and their family members to create an accessible dwelling.

Oliver (1992) argues that understanding the experience of disabilities in the environment can explain their problems from the limitations of the social environment as well as the accessibility of the physical environment. Understanding the lived experiences of disabilities requires an in-depth exploration of their daily life experiences, and does not place them as objects of research studies but as participants who are willing to share their experiences which may involve their physiological and psychological feelings. Thus, this study was conducted with visually impaired women as active participants, in the context of dwelling, to see and express the experiences in daily activities and setting based on the cognition of their senses. This study aims to see and formulate 
The $6^{\text {th }}$ International Seminar on Science and Technology (ISST) 2020

July $25^{\text {th }} 2020$, Institut Teknologi Sepuluh Nopember, Surabaya, Indonesia

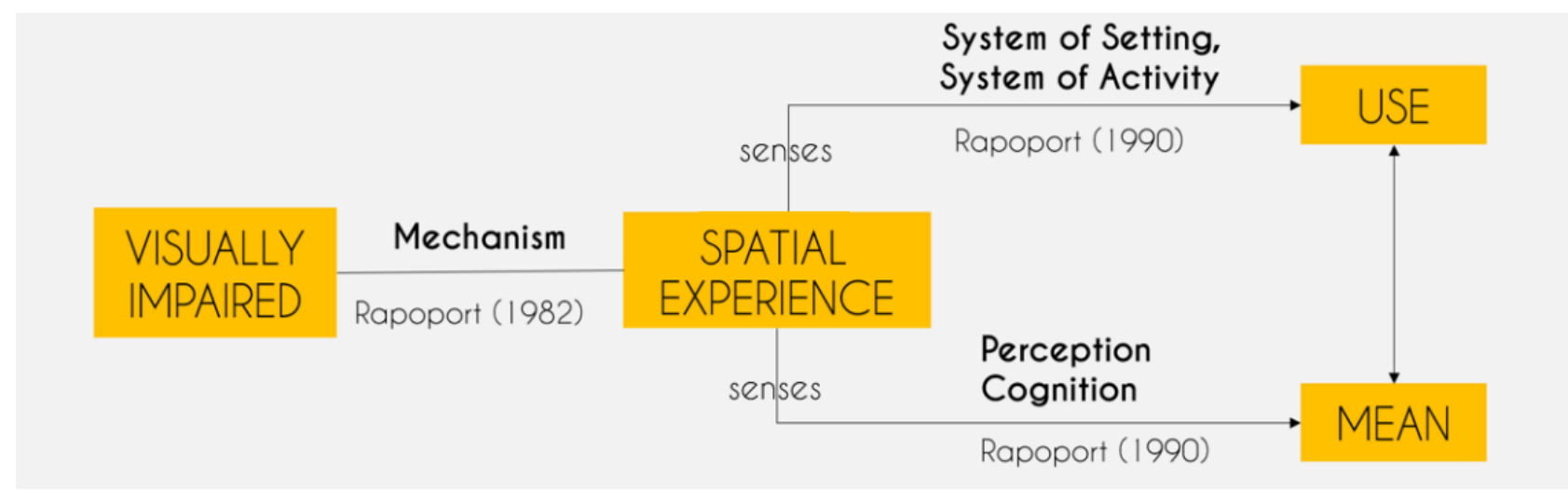

Figure 1. Visually Impaired and Space Experience Process on Research.

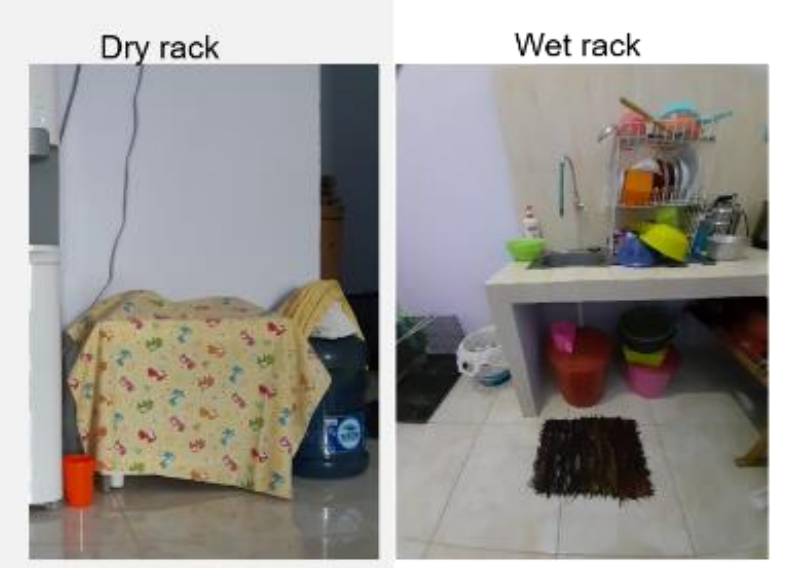

Figure 2. Storing Kitchenware as Staging Process in Coooking Activity.

how visually impaired compromise and create dwellings that can be accessed for daily activities.

\section{METHODS}

This phenomenological research used a naturalistic paradigm with a qualitative strategy, to emphasizes active and comprehensive observations (Miles \& Huberman, 1994), to provide an objective description. The steps in data collection include literature review, participant observation, and indepth interviews, to audio-visual documentation. Observation is carried out with participant observation where the researcher can hear, see, and experience the participant's activities. The method of selecting participants used in this study was purposive sampling, where the participants were chosen with specific criteria that are known from their nature (Surakhmad, 1994), including women/housewives, independent, active and productive. This research uses qualitative data analysis techniques by processing and analyzing the collected data into systematic, orderly, structured, and meaningful data. In this process, data grouping occurs by giving code/coding, i.e. grouping and merging data into a small number of themes (Creswell, 2013).

\section{RESULTS AND DISCUSSION}

Activities of visually impaired vary from daily bathing, sleeping, eating, cooking, washing clothes and dishes, drying, ironing, cleaning the house, watching TV/entertainment, praying, to storing. Personal activities are carried out in- dwelling demanded to be responsive and flexible to user activities that can change over time. Branham and Kane (2015) found that visually impaired work together to create an accessible home environment, called collaborative accessibility, through preparatory and intervention activities. The term collaborative accessibility refers to situations where family members, friends, or strangers help (or hinder) access to the use of space (Branham and Kane, 2015). From domestic activities that occur at home, cooking is an activity that involves the use of the senses dominantly. So, this paper will only explain cooking activity in deeply about how this activity carried out in accordance with the senses and another activity that affected.

Lakoff (1999) proposes that concepts are represented in the form of metaphors based on the basic experience of how the body interacts with the physical world. For example, how humans move in physical space. This is related to how mobility in the house, space arrangement, and storing strategies as a staging process in the preparation of activities, to maintaining the participant's following memory.

In the cooking activity, the staging process occurs when the participant starts storing the kitchenware. Kitchenware stored based on the classification of the use and also characteristics, can seen in Figure 2. According to Mrs. Riski, storing kitchenware must be done by her self, due to her memory. The use of dry rack and wet rack are the example of how Bu Riski classified the kitchenware based on the characteristics. While seasoning area and pan area are the classifications of the use. 


\section{Cooking Perkedel (Friying)}

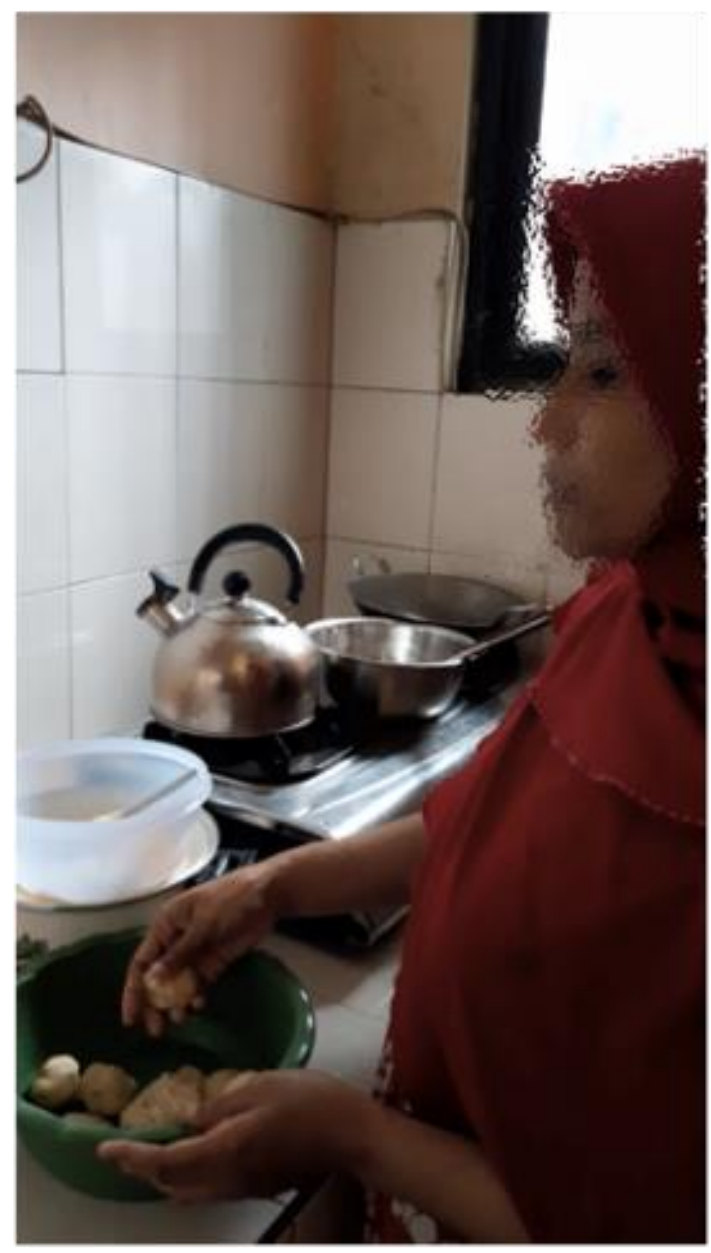

\section{4 pieces per process}

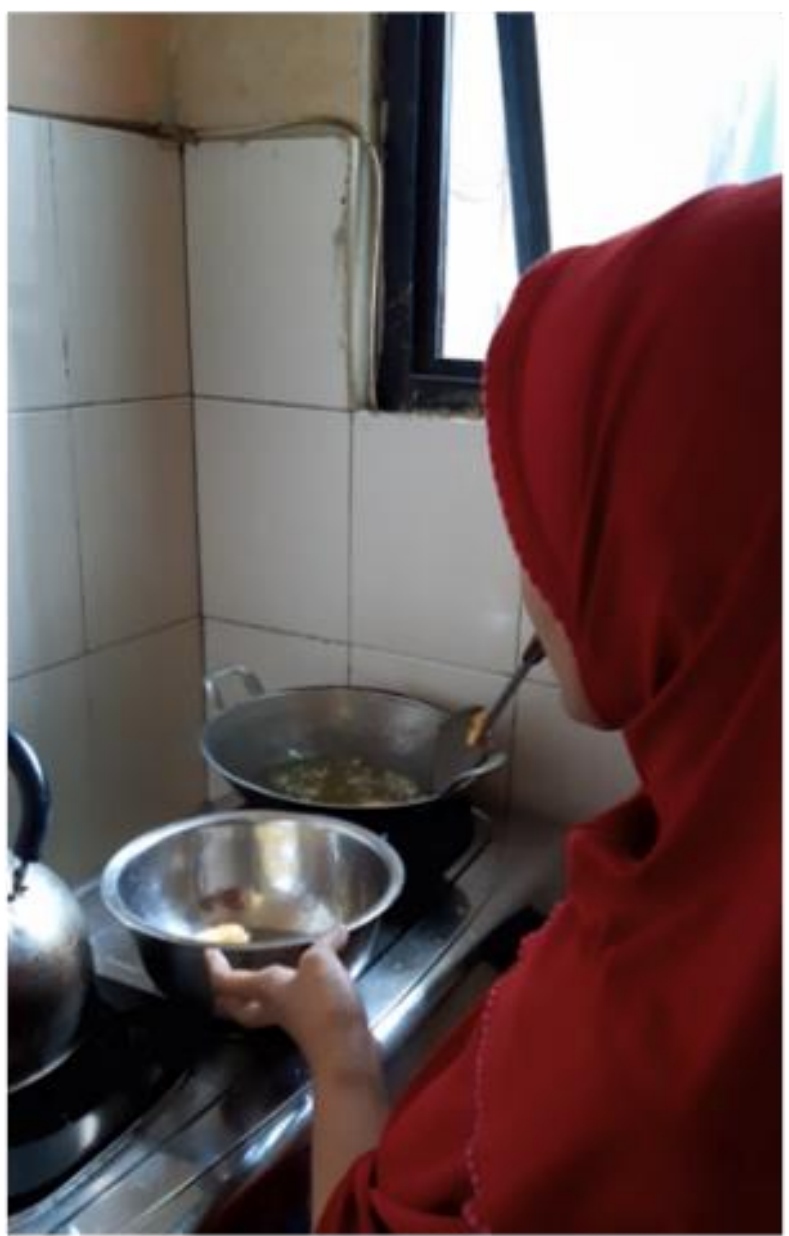

\section{Lift up cooked perkedel in containers without using an oil filter for fear of oil splashing}

Figure 3. Frying Perkedel as Part of Cooking Activity.

"For storing, we place them in accordance with the classified group. For example in the kitchen, there are dry rack, wet, rack, as well as seasoning and pan area. Those storing process must be done by myself. If not me, then I have to know so that I would not confused " (Mrs. Riski, 10.00 AM, 22 November 2019).

Besides storing, cooking activities themselves can be into frying, sautéing, and boiling, wherein each category has certain sensory stages and sensitivity. For example, in frying, Mrs. Riski must use a frying pan that is larger than the size of the food to be cooked, with approximately the food being fully immersed in oil and not splashed, can seen in Figure 3. The same thing was expressed by Mrs. Risa. Cooked food can be felt through the sense of olfactory (smell) and haptic (touch), to check the texture of crunchiness.
"Cooking activity such as frying is normal for me. I always fry with one pan for maximum of 4 pieces of food. For example, tofu, tempeh, or cake. Why 4? Because 4-piecespan-size would not let me confused about which ones have been cooked well, and which have not. Later with the smell, and if you scrape them, they will dry out. Just use the feeling "(Mrs. Risa, 11.00 AM, 15 February 2020).

When sautéing, the pan must be large and non-sticky so that it makes it easier for visually impaired to cook, can seen in Figure 4. According to Mrs. Riski, the senses that work are the sense of auditory (hearing) and olfactory (smell). Mrs. Riski said that the frying sound will be different if it is tapped when the food is still raw and when it is cooked. The sound produced will be more rounded than when it was still raw. 


\section{Cooking: Semur Ati (Sauteing)}

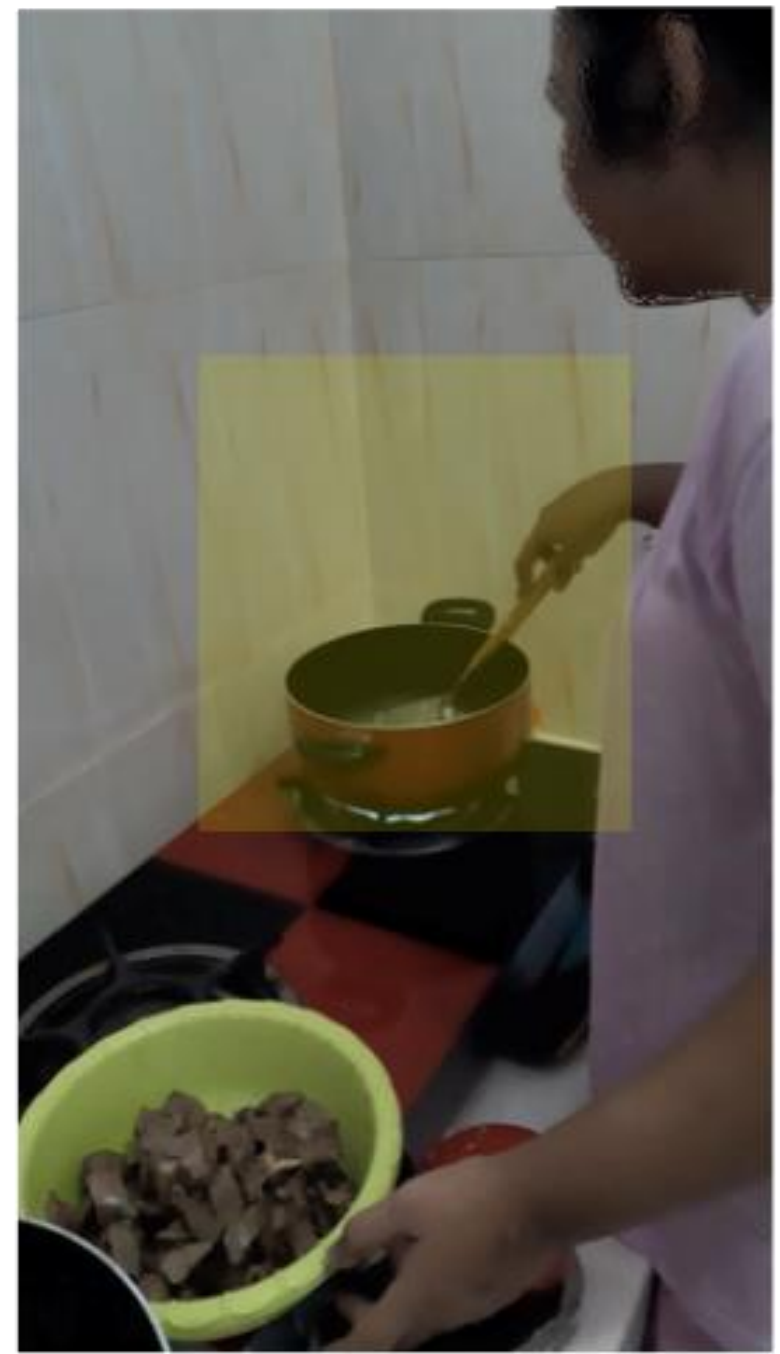

Hearing sensory works by tapping the pan with a spatula as a sign that food cooked well

Figure 4. Sauteing Semur Ati as Part of Cooking Activity.

Similarly, with the boiling process in Figure 5, visually impaired must ensure that the pan for cooking is large enough to accommodate the food when it is still raw until cooked. The most dominant working senses are auditory (hearing), haptic (touch), and olfactory (smell). Auditory to hear the sound of boiled water/food, haptic to feel hot steam, and olfactory to smell the aroma of cooking.

"When cooking, we rely on olfaction, as same as feeling. How long has it been stirred while we tasted. Besides, hearing also plays an important role. We try to tap the pan with a spatula, it will produce sounds that are different when

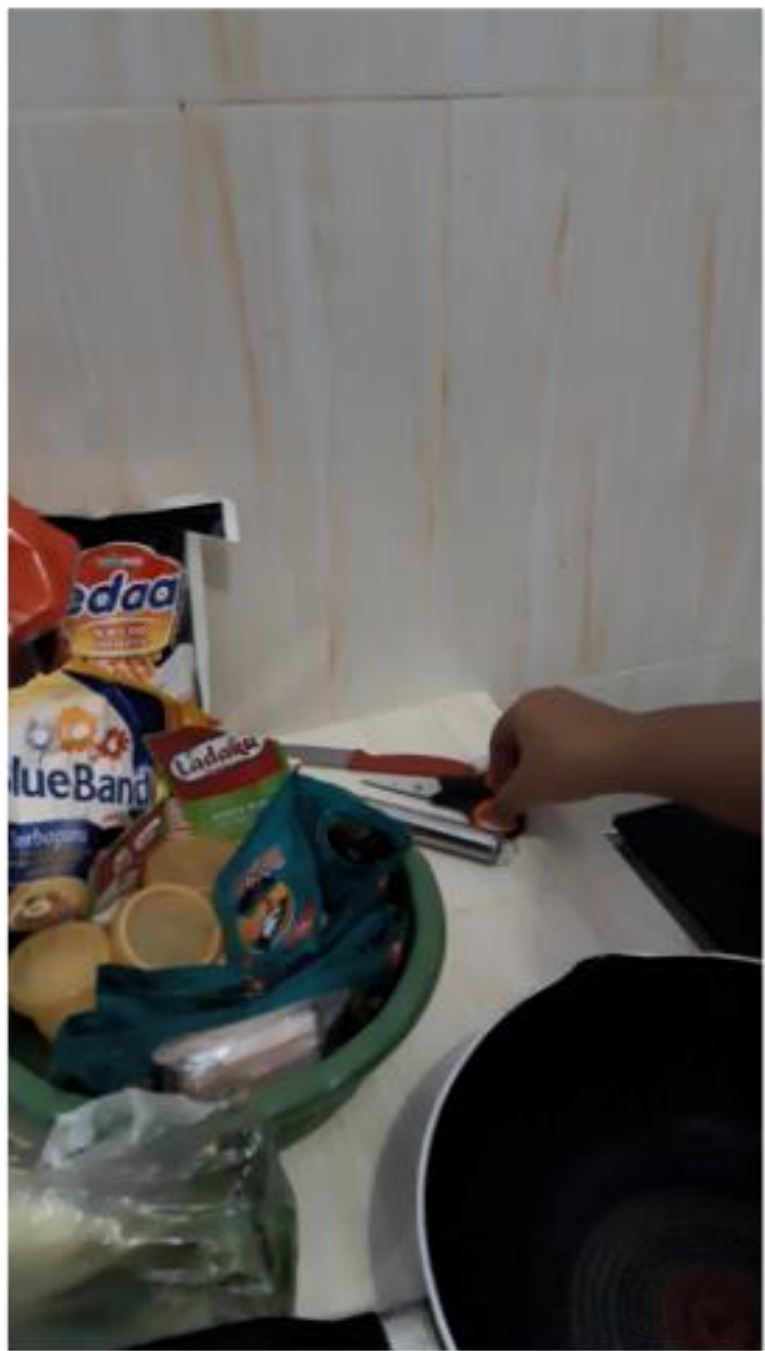

\section{Sachet packaging as an assistive in the doses of seasoning}

it is still raw and cooked well. I got this knowledge from a cooking demonstration "(Mrs. Riski, 12.00 PM, 23 November 2019).

As main activities, cooking also involved another activity as the secondary activities. On of the secondary activities has been identified as storing at the beginning of the cooking process. Besides storing, another activity can be done while cooking activity is on the process, for example, washing dishes, preparing food materials, as well as nurturing. Those phenomena occur due to the boundaries identification based on the participant's sensory. Cooking activities themselves 


\section{Cooking Puding (Boiling)}

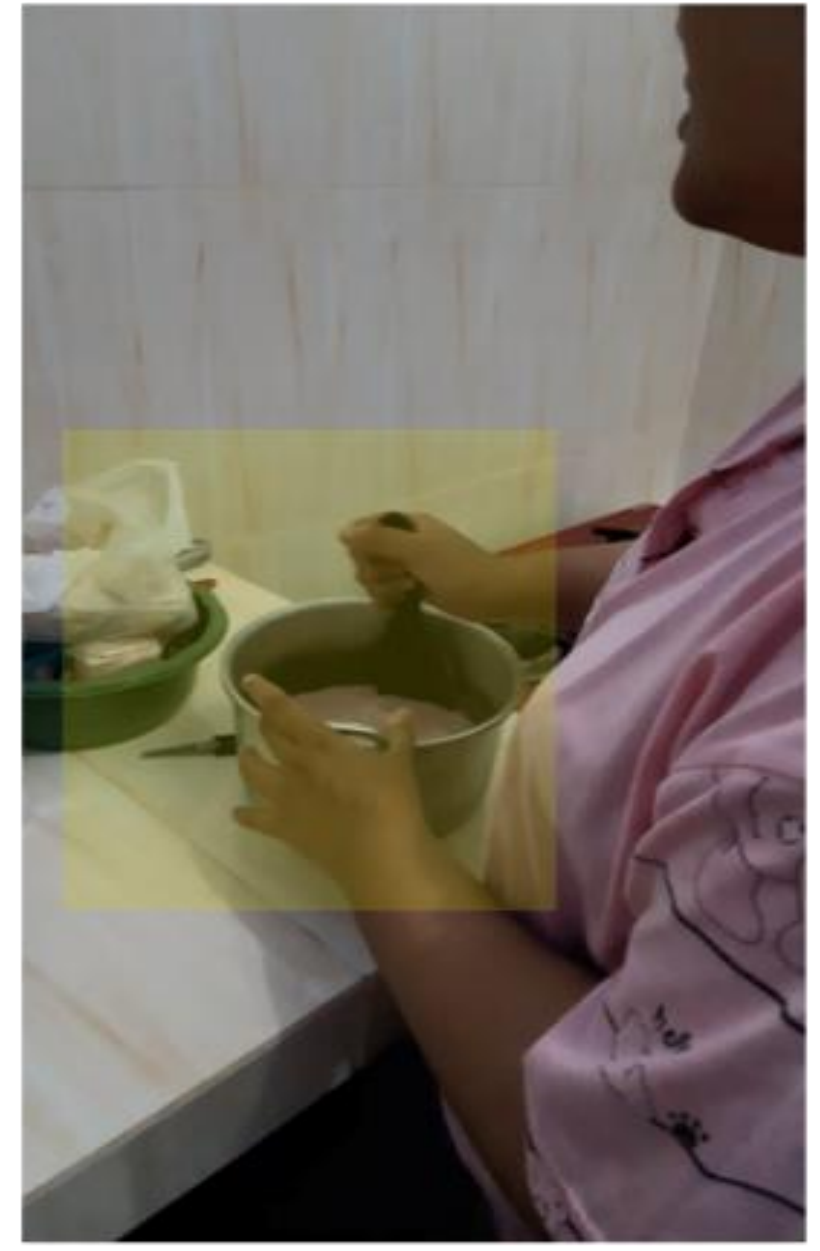

\section{Dissolve the puding mixture before heating to avoid clot}

Figure 5. Boiling Puding Mixture as Part of Cooking Activity.

include the senses of auditory, olfactory, and haptic. Each sense determines their own space boundaries as shown in Figure 6 . That boundary aware participants while doing the secondary activities, whether they still hear or smell the food or not, or, whether the sound or the smell is different or still the same, as their safe area.

\section{CONCLUSION}

Vision can be an external stimulus that can be used as a landmark or reference tool (Millar, 1981a). So that when there is no external stimulus reached visually impaired, they must take action to maintain contact with the environment (von Senden, 1960). Therefore the use of senses and sensitivity plays an important role in supporting visually

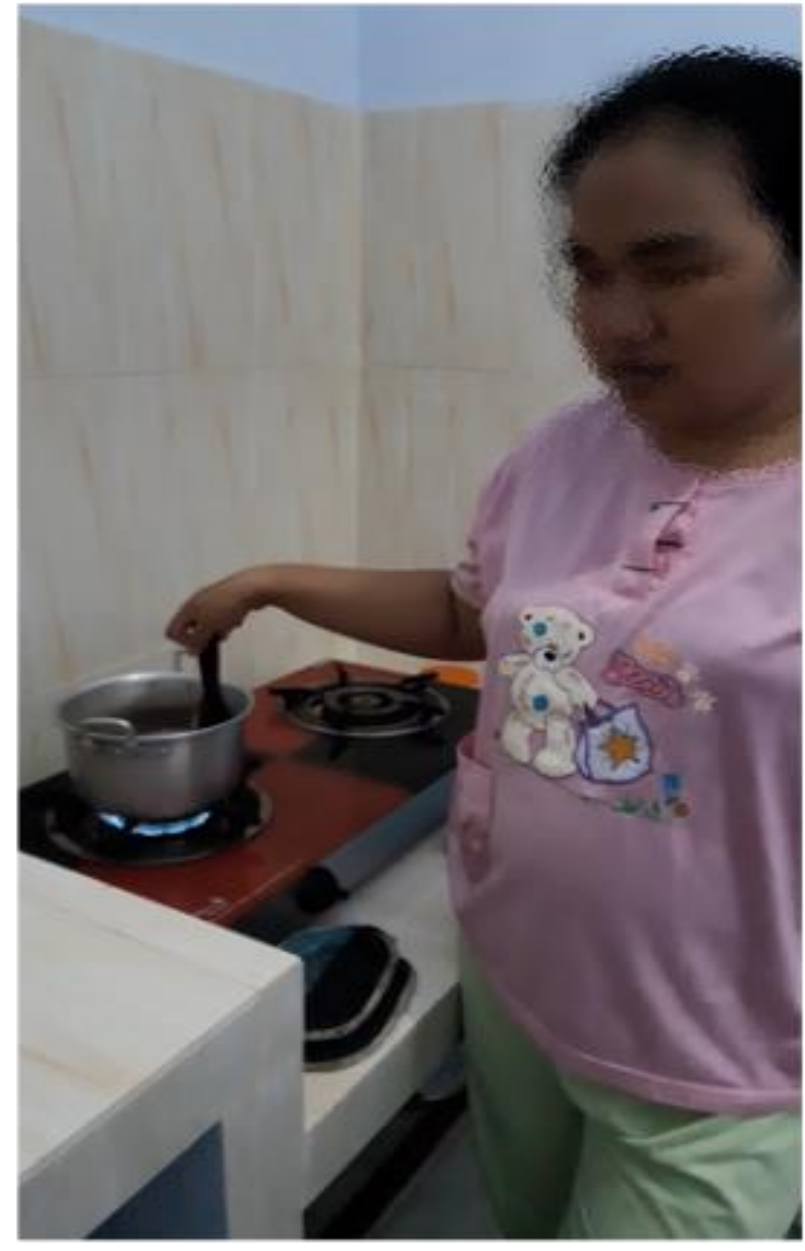

\section{Stir the puding mixture}

impaired to move. Acoustic features, tactile / touch experience, and smell are features that define the identity of a place (Basyazici, 2013). Cooking activities such as frying, boiling, and sauteing, each category has certain sensory stages and sensitivity. Frying uses active senses namely auditory, olfactory, and haptic. Sauteing uses the senses of auditory and olfactory. Likewise boiling, the senses that work most dominant are auditory, haptic, and olfactory. While storing activity only use haptic as the sensory, and memory as the representation. Activities and senses that work influence another activity of visually impaired. The reach of each of the senses will determine the boundaries of how visually impaired doing other activities. For example, washing as a side activity while waiting for cooking as the main activity. The scheme of space use in activities and 


\section{Cooking (Bu Risa)}

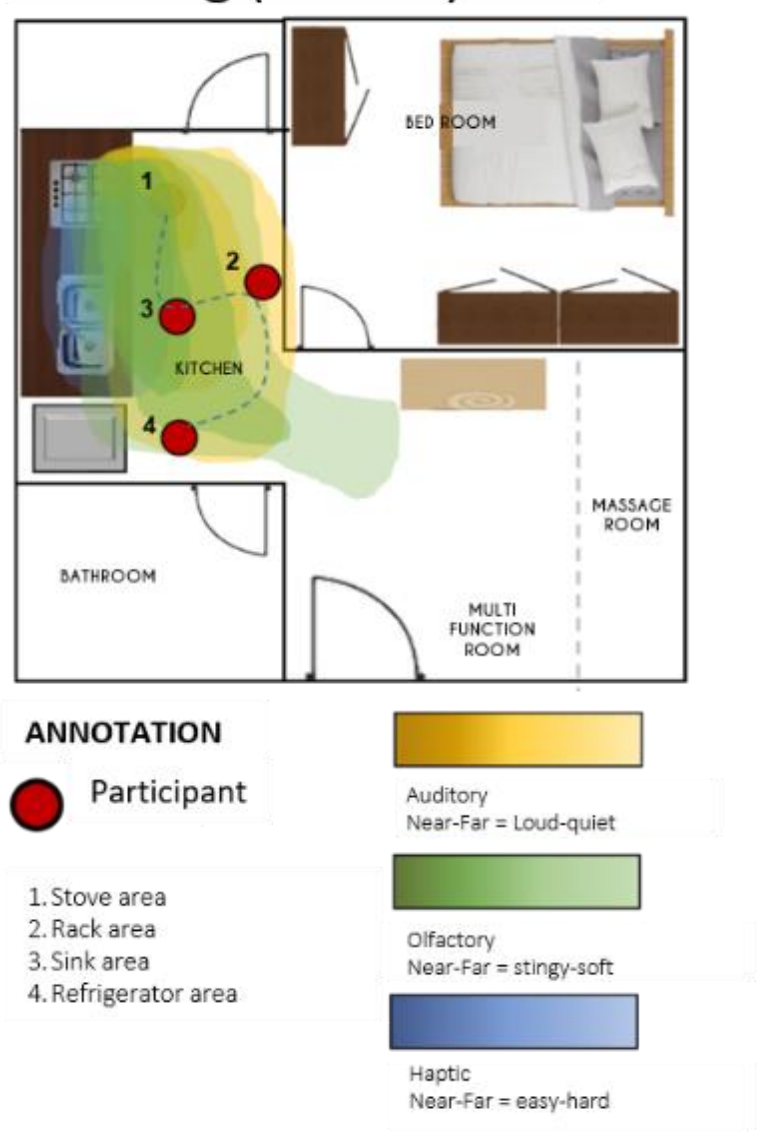

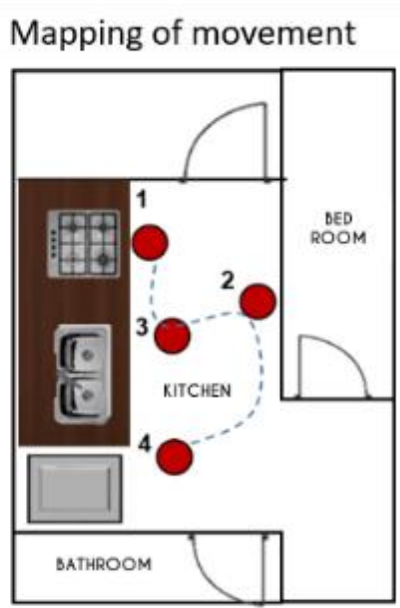

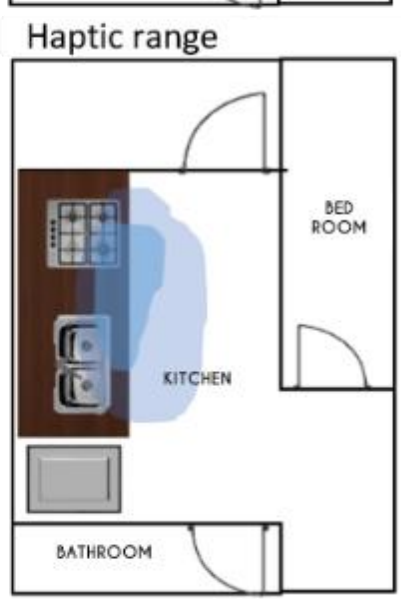

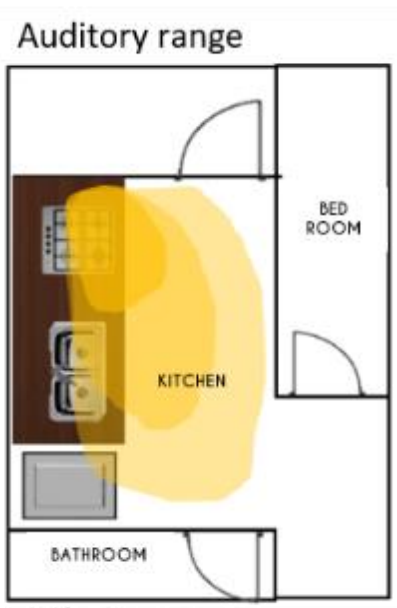

Olfactory range

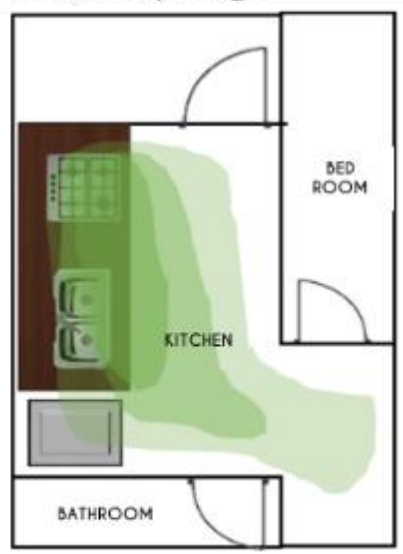

Figure 6. Mrs. Risa's Physical and Sensory Mapping Movements in Cooking Activities.

sensory coverage has been presented in Figures 6 related to cooking and sensory activities that work for Mrs. Risa.

\section{ACKNOWLEDGEMENT}

This paper is part of the master's thesis research and supported in part by Master Thesis Research Grant Year 2020 funded by Deputi Bidang Penguatan Riset dan Pengembangan, Kementrian Riset dan Teknologi / Badan Riset dan Inovasi Nasional.

\section{REFERENCES}

[1] Oswald, D. (1987). The Organization of Space in Residential Buildings: a Cross-Cultural Perspective. in Kent, S. (ed.) Method and Theory for Activity Area Research: an Etnoarcheological Approach. Columbia University Press, New York.

[2] Rapoport, A. (1990). Systems of Activities and Systems of Settings. In S. Kent (Ed.), Domestic Architecture and the Use of Space (pp. 9-20). Cambridge: Cambridge University Press.

[3] Creswell, J.W. (2013). Qualitative Inquiry and Research Design: Choosing Among Five Approaches: SAGE Publications.

[4] Hemingway, L. (2011). Disabled People and Housing: Choices, Opportunities and Barriers: Policy Press.

[5] Lakoff, George. (1999). Philosophy in the flesh : the embodied mind and its challenge to Western thought / George Lakoff and Mark Johnson. New York, N.Y: Basic Books.

[6] Miles, M.B., \& Huberman, A.M. (1994). Qualitative Data Analysis: An Expanded Sourcebook: SAGE Publications.

[7] Surakhmad, W. (1994). Pengantar penelitian ilmiah: dasar, metode dan teknik: Tarsito.

[8] Imrie, Rob. (1998). Focusing on Disability and Access in the Built Environment. Disability \& Society, 13(3), 357-374. doi: $10.1080 / 09687599826687$.

[9] Oliver, Mike. (1992). Changing the Social Relations of Research Production? (Vol. 7).

[10] Rapoport, Amos. (1998). Using "Culture" in Housing Design. Housing and Society, 25(1-2), 1-20. doi: 10.1080/08882746.1998.11430282.

[11] Sixsmith, Judith. (1986). The meaning of home: An exploratory study of environmental experience (Vol. 6).

[12] Branham, Stacy M., \& Kane, Shaun K. (2015). Collaborative Accessibility: How Blind and Sighted Companions Co-Create Accessible Home Spaces. Paper presented at the Proceedings of the 33rd Annual ACM Conference on Human Factors in Computing Systems, Seoul, Republic of Korea.

[13] Basyazici, Burcin. (2013). A phenomenological study of spatial experiences without sight and critique of visual dominance in architecture.

[14] Hidayatun, M. I. (2008). Hakekat Ruang Dalam Arsitektur Tradisional Sebagai Satu Bentuk Jawaban Dari Tantangan Alam (Studi Tentang Arsitektur Tradisional Vernakular),. Paper presented at the Seminar Nasional Jelajah Arsitektur Tradisional Nusantara Dalam Menemukenali Teknologis Berbasis Kearifan Lokal Makassar. 